\title{
Organizational learning capability, product innovation performance and export intensity
}

\author{
Accepted for publication in Technology Analysis \& Strategic Management (10/06/2011)
}

\section{Authors:}

Joaquín ALEGRE (Corresponding author)

University of Valencia

Dpt. of Management 'Juan José Renau Piqueras'

Av. Tarongers, s/n. 46022 Valencia (Spain)

e-mail: joaquin.alegre@uv.es

Tel: ++34963 828877; Fax: ++3496382833

José PLA-BARBER

University of Valencia

Dpt. of Management 'Juan José Renau Piqueras'

Av. Tarongers, s/n. 46022 Valencia (Spain)

e-mail: jose.pla@uv.es

Tel: ++34 963 828917; Fax: ++34 96382833

Ricardo CHIVA

University Jaume I

Dpt of Business Administration and Marketing Av. Sos Baynat, s/n. 12071 Castellón (Spain)

Telf: ++ 34 964387111; Fax: ++ 34964728629

e-mail: rchiva@emp.uji.es

Cristina VILLAR

University of Valencia

Dpt. of Management 'Juan José Renau Piqueras'

Av. Tarongers, s/n. 46022 Valencia (Spain)

e-mail: cristina.villar@uv.es

Tel: ++34963828750 ; Fax: ++3496382833

\section{Authors' note:}


Joaquín Alegre is Associate Professor at University of Valencia (Spain) where he teaches subjects related to strategy and innovation management. He holds a $\mathrm{PhD}$ in Management from University Jaume I. In 2002, he was a visiting researcher at INSEAD (Fontainebleau, France). His research interest focuses on organizational learning, knowledge management and innovation from a strategic perspective. Dr. Alegre has published articles in journals such as Research Policy, Journal of Product Innovation Management, British Journal of Management, or Technovation.

José Pla-Barber is Professor of International Business at University of Valencia (Spain). During 2009, he was the president of the European International Business Academy. His research focuses on international business and international marketing. Dr. Pla_Barber has published articles in Journal of International Marketing, International Marketing Review, Journal of Business Research, and International Business Review, among others.

Ricardo Chiva is Associate Professor at Universitat Jaume I (Spain) where he teaches subjects related to human resource management. He holds a $\mathrm{PhD}$ in Management and an International MBA from the European School of Management (ESCP-EAP). His areas of interest are organizational learning, design and innovation management, complexity theory and human resource management. Dr. Chiva has published articles in Journal of Product Innovation Management, International Journal of Management Reviews, and Management Learning, among others.

Cristina Villar is Professor Assistant at University of Valencia (Spain) where he teaches subjects related to strategic management. She holds a PhD in Management on organizational learning, innovation and exports. Dr. Villar has published articles in journals such as Service Industries Journal or Service Business.

Acknowledgements. The authors would like to thank the Ministry of Science and Innovation (SEJ2006-13889/ECON and ECO2008-00729) for their financial support for this research. 


\title{
Organizational learning capability, product innovation performance and export intensity
}

\begin{abstract}
:
The purpose of this paper is to provide a more complete picture of the relationship between organizational learning capability (OLC) and export intensity, by taking into consideration the mediating effect of innovation performance. Based on expectations from the ResourceBased View and International Marketing, structural equation modeling was used to assess simultaneously the links between OLC, innovation performance, and export intensity. Adopting a longitudinal perspective, perceptual and objective data were collected from 182 Italian and Spanish ceramic tiles producers. This study shows that firms with a higher OLC tend to be more innovative, and for this reason, they are more likely to export a higher share of their production. Because we have carried out a single industry analysis, caution should be used in generalizing from these findings. Our study contributes to the international marketing literature by supporting the perspective that a firm's export intensity depends on its innovation performance, by also taking into account that the latter is affected by OLC. We thus provide a better understanding on the links between two internal key antecedents to export intensity. Organizational learning facilitating factors should be taken into account when setting innovation and export objectives. Managers can foster the enhancement of such factors, in the knowledge that these are likely to have an impact on innovation and export intensity. This paper connects organizational learning, innovation and exports on a simultaneous basis. Findings highlight a range of strategic benefits resulting from enhancing OLC.
\end{abstract}




\section{Introduction}

Exporting is fast becoming crucial factors in company performance and survival as a result of the evolution of the competitive environment (Golovko and Valentini, 2011). The increasing engagement of firms in export activities is now one of the most visible responses to the constantly changing dynamics of the global environment. Exporting plays a vital role in company strategies and its importance is expected to grow further as markets become increasingly globalized. Exporting helps to develop competitive advantages, improves managerial skills and financial performance, facilitates company growth and can even ensure company survival (Anderson and Gatignon, 1986; Grupp, 1997). Organizational learning has been found to be an important input for exporting (Ling-Yee, 2004; Petersen, Pedersen and Lyles, 2008).

Exporting can be conceived as individual and collective learning processes that aim to search new ways of solving problems (Kafouros et al., 2008). An exporting company faces problems such as choosing the adequate segments and distribution channels to be successful in international markets..

In this study, we look at what initiatives could be taken by managers in order to support those learning processes that might be beneficial for exporting. We argue that the concept of organizational learning capability (DiBella et al., 1996; Goh and Richards, 1996) could provide a useful insight in determining such management initiatives because it is based on a number of organizational and managerial facilitating factors of the organizational learning process. Our first objective is to examine the effect of organizational learning capability (OLC) on export intensity.

Innovation is commonly defined as adopting an idea or behavior in relation to a product, service, instrument, system, policy or program which is new to the company 
(Damanpour and Evan, 1984). Product innovation consists of successfully implementing creative ideas within an organization (Amabile et al., 1996), and is therefore closely related to organizational learning. Because product innovation has also been found to affect positively exports (Rogers, 2004; Pla-Barber and Alegre, 2007), we argue that product innovation plays a boosting role in the exporting process. Our second objective is, therefore, to analyze if product innovation performance could be a mediator between OLC and export intensity.

Finally, drawing on the Resource-Based View (RBV), our third objective is to explain intra-industry differences in export intensity as a function of the interaction between OLC and product innovation performance (Zott, 2003).

This paper is structured as follows. Following a theoretical framework to define the concepts, we develop our hypotheses on the relationships between OLC, product innovation performance and export intensity. Then, we explain the research methodology and test the hypotheses using an international database from Italian and Spanish ceramic tile manufacturers. We conclude with a discussion of the results highlighting their implications and suggesting future lines of research.

\section{Conceptual framework and hypotheses}

Resource-based view (RBV) is an influential theoretical framework for understanding the creation and sustainability of competitive advantage, and has been widely used to explain the internationalization of firms, especially in the context of exports (Katsikeas, Leonidou and Morgan, 2000; Dhanaraj and Beamish, 2003). Within this perspective, organizations can be understood as a set of unique and heterogeneous resources that can be valuable, rare, difficult to imitate and non substitutable. This type of resources can persist over time, constituting the foundation of competitive advantage in both domestic and international markets (Fahy, 2002; López-Rodríguez and García-Rodríguez, 2005). 
Internationalization and innovation have become crucial activities for firm's competitiveness. Given the growing importance of internationalization in recent years, a significant number of empirical works have tried to understand the key antecedents of export performance as posited by RBV. Dhanaraj and Beamish (2003) grouped these export determinants into three types of resources: organizational, entrepreneurial and technological resources. Basile (2001) considered four determinants: 1) innovative activity, 2) organizational characteristics, such as size or structure, 3) characteristics of the sector, and 4) location. At present, despite the academic effort that has been undertaken in the past 30 years, literature on the determinants of export performance has not yet established a strong theoretical basis (Sousa et al., 2008). Nevertheless, generally speaking research on internationalization has proposed that export performance depends on structural factors of the company (such as size, age, organization systems or R\&D intensity), managerial factors, and incentives and obstacles to the internationalization process (Bonaccorsi, 1992). Managerial commitment is one of the most supported variables in this literature, as it highly determines the proactiveness to seek for opportunities in the market (Chetty and Hamilton, 1993), especially in SMEs, in which decisions on international strategy usually are due on a person or a reduced management team (Boter and Holmquist, 1996; Fernandez and Nieto, 2005).

In line with this, one of the main factors that might enhance a firm's international activity is organizational learning, which has been identified as a key factor for achieving competitive advantage in dynamic and turbulent markets. Organizational learning can be understood as the process of social construction of shared beliefs and meanings, in which the social context plays an essential role (Chiva and Alegre. 2005). Previous research has linked organizational learning to important competitive issues such as market orientation (Zhou et al., 2005), product innovation (McKee, 1992; Hurley and Hult, 1998), project performance (Wu and Fang, 2010), and firm performance (Calantone et al., 2002; Hult et al., 2004). 
The concept of OLC (DiBella et al., 1996) is anchored inside the organization and underlines the importance of the facilitating factors of organizational learning. Goh and Richards (1997) define OLC as the organizational and managerial characteristics or factors that facilitate the organizational learning process or allow an organization to learn. Recently, Chiva and Alegre (2009a) proposed a new and integrative conceptualization of OLC following a comprehensive analysis of all the theoretical perspectives and literatures involved in the facilitating factors of organizational learning. Five facilitating factors of organizational learning were identified: experimentation, risk taking, interaction with the environment, dialogue and participative decision making.

This conceptualization implies the following: on the one hand, these five dimensions are essential enablers of the organizational learning process that are set and promoted through managerial intentionality (Hutzschenreuter et al., 2007); on the other hand, they represent the organizational learning capability of a particular firm. Although the concept of OLC was developed from the organizational learning literature, it is linked to the RBV and to the organizational capabilities perspective (Lages et al., 2009). The development of organizational capabilities such as OLC requires the integration of specific resources. Moreover, its development and its application over time make them embedded and distinctive, providing a source of competitive advantage (Tippins and Sohi, 2003).

In general, firms that are able to learn about other organizations (customers, suppliers, and competitors), market evolution and technology changes stand a better chance of sensing and acting upon dynamic environments (Zollo and Winter, 2002; Wu and Fang, 2010). Learning oriented organizations are in a better position to outperform their competitors with regard to innovation, customer retention and sales growth (Toften and Olsen, 2003; Tippins and Sohi, 2003). 
From this perspective, exporting is viewed as a process of learning and knowledge accumulation during which the company identifies and exploits opportunities abroad (Li et al., 1998; Ling-Yee, 2004; Brouthers et al., 2009). Firms that learn efficiently from their experience are able to export faster and with fewer mistakes. Knowledge renewal and exploitation regarding foreign markets may increase exports (Balabanis et al., 2004), and export intensity is said to be enhanced by an organization's ability to learn. As exporting is trial-and-error based and firms have imperfect knowledge of the institutions and customers in the foreign market, knowledge of both is accumulated by conducting international operations. Learning alters the manner in which firms see and interpret the world and identify knowledge gaps in foreign markets (Petersen et al., 2008). This accumulated knowledge drives exporting and improves a firm's capabilities to monitor and collect information. This new knowledge is assimilated into the firm's existing knowledge.

Fostering OLC represents a way in which managers attempt to implement initiatives that facilitate learning processes. Exporting effectively through time might be understood as a learning process through which firms adapt to international customers (Balabanis et al., 2004). As a result, the better the firm's OLC, the greater the probability of success in its international activities will be. Therefore, we hypothesize:

H 1: OLC has a positive effect on export intensity.

However, we find theoretical support to argue that this positive effect might be mediated by product innovation. Innovation reflects the tendency to engage and support new ideas and creative processes that may lead to new products, services or technological processes (Lumpkin and Dess, 1996). Hence, it is generally proposed that the ability to innovate is one of the main factors contributing to create competitive advantage, increasing efficiency and improving competitiveness, thus helping to ensure its future performance. Innovation requires that two conditions be met: novelty and use. In general, the requisite of 
novelty is verified since the innovation process puts into practice an invention, a scientific discovery or a new production or management technique. The requisite of utility is borne out through its use or commercial success (Alegre et al., 2009).

We argue that between those organizational characteristics that facilitate organizational learning (OLC) and final organizational outputs such as exporting, there are a number of intermediate processes (Tippins and Sohi, 2003; Wang, 2008). We claim that product innovation is likely to play an important role between learning processes and firm's exports. In fact, organizational learning can be soundly linked to innovation outcomes. Zaltman, Duncan and Holbek (1973) point out that a critical part of the first stage of the innovation process is openness to the innovation; that is, whether the members of an organization are willing to learn and change or are resistant to innovation. Knowledge is the output of the learning process and the input of the innovation process.

In this vein, McKee (1992) understands product innovation as an organizational learning process and claims that directing the organization towards learning fosters innovation effectiveness and efficiency. OLC enhances knowledge creation and integration; this knowledge constitutes a crucial input for the innovation process (Li et al., 1998; Lages et al., 2009). Wheelwright and Clark (1992) suggest that learning plays an essential role in new product development projects because of changing environmental factors such as customer demand uncertainty, technological developments or competitive turbulence. Furthermore, a number of scholars consider learning orientation as an antecedent of innovation (Hurley and Hult 1998; Calantone et al., 2002; Hult et al., 2004). Orientation towards markets provides sources of ideas for change and improvement that will be appreciated and effectively assimilated into new product developments by adopting a learning orientation.

Finally, the technology and innovation management literature generally predicts that innovative firms will tend to enter foreign markets in order to increase sales volume and 
spread the fixed costs of innovation over a larger number of units (Rogers, 2004). The technology and innovation management literature provides evidence of a positive relationship between product innovation and export intensity (Atuahene-Gima, 1995; Pla-Barber and Alegre, 2007). Innovation confers market power and, as a consequence, facilitates exports (Roper and Love, 2002; Quintás et al., 2009). In this vein, Zou and Ozsomer (1999) suggest that firms with a higher level of innovation have a greater dependence on international markets and vice versa. As a result, innovation could be a channel through which OLC reinforces exports. Innovation allows the firm to replace their products by more attractive and updated ones or to adapt them to international markets tastes (OECD, 2005; Golovko and Valentini, 2011)). Therefore, we argue that the link between OLC and export intensity is mediated by product innovation performance. The following hypothesis is put forward.

\section{H 3: The effect of OLC on export intensity is mediated by product innovation performance.}

Hypothesis 3 complements hypotheses 1 and 2 in the sense that it sheds more light in the intermediate steps between the organizational and managerial characteristics that facilitate learning (OLC) and export intensity (Wang, 2008). We argue that product innovation is going to be an important intermediate process within the link between OLC and export intensity.

\section{Methodology}

\section{Sample and Data Collection Procedure}

Processes related to organizational learning and innovation, as well as the outcomes of those processes, might differ substantially from one industry to another. For this reason, we chose to focus on a single industry in an international context: Italian and Spanish ceramic tile producers. 
Italian and Spanish ceramic tile production in 2004 represented 77\% (Ascer, 2004) of EU production. The world's biggest ceramic tile producer is China, followed by Spain, Italy, Brazil and Turkey. However, Spain and Italy are by far the world's largest exporters.

The ceramic tile industry is largely globalized. Italian and Spanish firms lead world ceramic tile exports thanks to superior technology, productivity, quality, and design (Ascer, 2004). These firms have substantial common traits. Most of them are considered to be Small and Medium Enterprises (SMEs), as they do not generally exceed an average of 250 workers. Moreover, they tend to be geographically concentrated in industrial districts: Sassuolo in Northern Italy and Castellón in Eastern Spain (Chamber of Commerce of Valencia, 2004). Previous studies provide compelling evidence of the significant innovating behavior of Italian and Spanish ceramic tile producers (Enright and Tenti 1990; Flor and Oltra, 2005).

Survey field work was undertaken from June to November 2004. A pre-test was carried out on four technicians from ALICER, the Spanish Centre for Innovation and Technology in Ceramic Industrial Design, to assure that the questionnaire items were fully understandable in the context of the ceramic tile industry. The questionnaire was applied using a 7-point Likert scale (Appendix).

A key informant technique consistent with previous studies was used to obtain data (Kumer et al., 1993). The questionnaire was addressed to two company directors (see Appendix). The Product Development Manager responded to the product innovation performance questions, while the Human Resource Manager answered items dealing with OLC. An appointment was made with the respondents so that the questionnaire could be answered in a personal interview. Following Malhotra (1993), we offered a feedback report on the survey results to the participating firms in order to encourage response.

Export intensity was obtained through secondary objective sources. We obtained these data with the collaboration of the Italian and Spanish ceramic tiles associations 
(Assopiastrelle, 2009; Ascer, 2009). We used exports data from 2006. Thus, we examine the effect of OLC and product innovation performance over the dependent variable with a time lag of two years.

This study combines primary data taken from two different key informants and secondary data for our final dependent variable. In this way we limit potential statistical problems such as common method variance.

We received a total of 182 completed questionnaires, 82 from Italian firms and 100 from Spanish firms. The sample obtained comes fully from the industrial districts in Sassuolo (Italy) and Castellón (Spain). It represents slightly less than half of the population under study, $45.30 \%$ for the Italian sub-sample and $49.27 \%$ for the Spanish one (Assopiastrrelle, 2009; Ascer, 2009). Non-response bias was assessed through a comparison of sample statistics and known values of the population such as annual sales volume and number of employees (Assopiastrelle, 2009; Ascer, 2009). No significant differences were found $(\mathrm{p}<0.05)$, thus providing no evidence for non-response bias.

\section{Measures}

$O L C$ is measured using the perceptual measure developed by Chiva and Alegre (2009a). This instrument comprises a set of scales that represent latent variables through their items. We conceived OLC as a construct with five different dimensions: experimentation, risk taking, interaction with the external environment, dialogue and participative decision making.

Product innovation performance is conceptualized as a construct with two different dimensions: innovation effectiveness and innovation efficiency (Alegre et al., 2009). Innovation effectiveness is focused on the degree of achievement of product innovation objectives. Our measure is based on a measurement scale provided by the OECD in the Oslo Manual (OECD, 2005). Innovation efficiency is determined by the resources (cost and time) involved in the firms' innovation projects (Wheelwright and Clark, 1992). 
Export intensity represents the share of exports in total sales for a particular firm. This variable is a widely used indicator in empirical international marketing research (Majocchi et al., 2005).

\section{Control variables}

Firm size was included as a control variable in the overall model since it could explain the variation in export intensity. Large companies are considered to possess more financial and human resources and higher economy of scale levels. These characteristics facilitate their entry into international markets (Leonidou et al., 1998). Moreover, small size is closely related to a number of export barriers (Leonidou, 1995; Piercy et al., 1998). Respondents were asked to classify their company into one of six categories according to the number of employees, devised ad hoc on the advice of the four ALICER technicians who participated in the study, and bearing in mind that the ceramic tile industry predominantly consists of SMEs. Table 1 shows the distribution of sample firms according to their size category and location.

Insert Table 1 about here

International marketing quantitative studies typically control for size, industry and international experience when considering export intensity as the dependent variable (Filatotchev et al., 2001). However, international experience has recently been found to be irrelevant in the ceramic tile industry (Flor and Oltra, 2005) due to the generalized exporter profile of ceramic tile producers. This is an industry in which all new entrants start by producing locally, but doing business on a global level (Enright and Tenti, 1990).

Analyses

The analyses of the data set are based on structural equations modeling (SEM) with robust indicators. We used EQS 6.1 software. 


\section{Results}

Psychometric Properties of Measurement Scales

The psychometric properties of the measurement scales were assessed in accordance with accepted practices (Gerbing and Anderson 1988), and included reliability, content validity, discriminant validity, and convergent validity. Table 2 presents factor correlations, means, standard deviations, and reliabilities.

We appraise reliability through two indicators: the Cronbach's alpha coefficient and composite reliability. Table 2 shows the reliability evaluation for each dimension. The composite reliability values and the Cronbach's alpha coefficients are highly satisfactory, all above 0.7 (Hair et al. 1998).

Insert Table 2 about here

Content validity was established through the use of previously validated measures and through personal interviews with ceramic tile industry experts (four ALICER technicians).

Discriminant validity was assessed through confirmatory factor analysis by comparing the $\chi^{2}$ differences between a constrained confirmatory factor model with an interfactor correlation set to 1 (indicating they are the same construct) and an unconstrained model with an interfactor correlation set free. All $\chi^{2}$ differences were found to be significant (Tables 3 and 4), providing evidence of discriminant validity (Anderson and Gerbing 1988; Gatignon et al 2002; Tippins and Sohi 2003). In the same vein, convergent validity was also confirmed by comparing the $\chi^{2}$ differences between a constrained confirmatory factor model with an interfactor correlation set to 0 (indicating that there is no relationship between the two constructs) and an unconstrained model with an interfactor correlation set free. All $\chi^{2}$ 
differences were found to be significant (Tables 3 and 4), providing additional evidence of convergent validity (Gatignon et al. 2002).

Insert Table 3 about here

Insert Table 4 about here

Testing of the Research Hypotheses

Adopting the approach used by Tippins and Sohi (2003), we tested one model for each hypothesis. The first model (H1: direct effect) examined the direct relationship between OLC and export intensity, while a second model (H2: partial mediation) examined the same relationship with innovation performance acting as a mediator.

Figures 1 and 2 show the results of both models. The chi-square statistic for each model is significant, but other relevant fit indices suggest a good overall fit (Tippins and Sohi, 2003). Results provide evidence that OLC has a positive effect on export intensity (See Figure 1; H1: $\alpha=0.51, t=6.80)$. Moreover, Figure 2 shows that innovation performance is mediating the relationship between OLC and export intensity for the following reasons. First, the partial mediation model explains more variance than the direct effect model $(0.625 \mathrm{vs}$. 0.301). Second, there is a positive and significant relationship between OLC and innovation performance $(\beta=0.70, t=7.78)$. Third, there is also a positive and significant relationship between innovation performance and export intensity $(\gamma=0.76, t=8.43)$. And fourth, the 
relationship between OLC and firm performance indicated in the direct effect model $(\alpha=0.51$, $t=6.80)$ becomes lower and non-significant in the partial mediation model $(\beta=0.03, \mathrm{t}=0.33)$.

Results are providing support to Hypothesis 1 and Hypothesis 2. There is a positive and significant effect of OLC over export intensity. However, the picture is more complete when we include the mediation of innovation performance. Innovation performance is playing a determinant role: the whole effect of OLC over export intensity $(\alpha=0.51, t=6.80)$ is generated through the action of innovation $(\beta=0.70, t=7.78$ and $\gamma=0.76, t=8.43)$. We have to remark that, as in previous mediations (Tippins and Sohi, 2003; Chiva and Alegre, 2009b) the outcome of multiplying $\beta(0.70)$ per $\gamma(0.76)$ is approximately $\alpha(0.51)$. The mediation model represents an advance over the direct effect model because it contains more significant information about the links between OLC and export intensity. The mediation model is not a substitute for the direct effect model, but an improvement.

In both models we controlled for the effect of size on the dependent variable. In the direct effect model size has a moderate but significant impact on export intensity. However, when innovation performance is included in the partial mediation model, size has a negligible and non-significant effect on export intensity. This means that innovation voids the moderate influence of size over export intensity. This is an interesting finding for the debate on the impact of size on innovation (Camisón-Zornoza et al., 2004; Pla-Barber and Alegre, 2007).

Insert Figure 1 about here

Insert Figure 2 about here 


\section{Discussion}

The possibility that the managerial characteristics that facilitate organizational learning (OLC) can provide firms with a basis for competitive advantage has received a great deal of attention in recent years. We have found a positive effect of OLC over export intensity. However, while previous research has found that organizational learning directly affects different internationalization processes, we argue that intermediate variables, such as innovation, should be used in order to evaluate its impact in organizations. This research shows that OLC enhances product innovation performance, which indirectly contributes to export intensity.

Product innovation performance is positively related to export intensity. This provides confirmation of previous findings on the benefits of product innovation effectiveness and innovation efficiency. Moreover, OLC has been found to be an important antecedent of product innovation performance. However, the literature identifies other antecedents of product innovation performance that have not been taken into account in this study such as knowledge strategy (Revilla and Rodriguez, 2011) or absorptive capacity (Volberda, Foss and Lyles, 2010). These product innovation performance antecedents could be considered indirect drivers of export intensity.

Furthermore, because OLC is a latent concept its five dimensions are expected to covary with one other with one other and to have the same antecedents and consequences Mackenzie et al. (2005). This implies that high levels of experimentation, risk-taking, interaction with the environment, dialogue and participative decision-making are expected to generate high product innovation performance.

This study also offers new evidence for the RBV. New trends in RBV research suggest that research should not only identify the critical specific assets within a particular industry, but should also make efforts to obtain additional understanding of the whole 
competitive advantage creation process by considering the role of organizational capabilities. Our findings show that innovative firms are more likely to be more successful in export markets and that OLC is a capability that enhances product innovation. As a result, those firms that have fostered OLC are in a better position to innovate and to export. Over time, this could generate a virtuous circle in which the interactions between these three variables would reinforce each other.

Our study contributes to the international marketing literature by supporting the perspective that a firm's export intensity depends on its product innovation performance, by also taking into account that the latter is affected by OLC. We argue that these key antecedents are subject to managerial intentionality and are assumed to enhance learning-based aspects of internationalization. Our findings provide an interesting insight to the debate on export determinants: OLC could be considered as a managerial (Bonaccorsi, 1992) or entrepreneurial (Dhanaraj and Beamish, 2003) factor that improves the use of the technological resources of the firm. As a result of this, product innovation performance is enhanced. Finally, this has a booster impact over exports.

\section{Managerial implications}

Our results show that when an organization develops certain practices (OLC), it is more able to learn, to develop new knowledge and consequently to innovate. Through innovation, firms generate new products that are more attractive or more technology-advanced. Innovation may also be useful to adapt existing products to overseas tastes and demands.

Furthermore, this study underscores the importance of managerial emphasis on organizational features that enhance learning. Organizational learning facilitating factors should be taken into account when setting innovation and export objectives.

\section{Limitations and future research}


Our findings must be viewed in the light of the study's limitations. We have developed a time-lagged study; however OLC and product innovation performance are measured at the same time. While it is likely that the conditions under which the data were collected will remain essentially the same, there are no guarantees that this will be the case. Moreover, because we have carried out a single industry analysis, our study has benefited from dealing with firms that are likely to be economically and technologically homogeneous. However, it must be stressed that single industry conclusions should be considered with caution.

In this study we have focused on the impact of OLC and product innovation performance on export intensity. The international marketing literature claims that exporting could also have an effect on OLC and product innovation performance (Kafouros et al., 2008). Failing to consider this reverse effect could be understood as a limitation. However, recently Salomon and Jin (2008) found that learning from exporting is significantly higher in laggard industries that in technologically leading industries. For this reason, this could be a moderate problem for our research.

Future research could point at obtaining longitudinal evidence including reverse effects. Moreover, cross-national studies are still needed to compare ceramic tile producers with different technology levels and specific cultural features: an interesting line would be to compare Italy and Spain with other relevant global producers such as China, Brazil or Turkey.

Complementary qualitative research could provide a more in-depth picture of a variety of cases within the sample. Such an analysis would depict specific situations that fall outside the norms of the hypotheses put forward in this study. An interesting case would be the one of those companies that could be successful exporting without innovating.

An additional line of research could be to include in the model additional marketing variables such as market orientation or export performance (Cadogan et al., 2009) or more 
antecedents of innovation performance. Further studies are also required to confirm the applicability of these findings to industries that differ substantially from that of ceramic tile production in terms of technology, organizational learning or modes of entry. Finally, another future line of research could be to examine in detail the organizational learning processes that are facilitated by OLC and to look at the role played by different types of learning (Wang, 2008) regarding innovation and exports.

\section{References}

Alegre, J., Chiva, R. and Lapiedra, R. 2009. Measuring innovation in long product development cycle industries: an insight in biotechnology. Technology Analysis \& Strategic Management, 21, (4), 535-546.

Amabile, T., Conti, R., Coon, H., Lazenby, J. and Herron, M., 1996. Assessing the work environment for creativity. Academy of Management Journal, 39(5): 1154-1184.

Anderson, E. and Gatignon, H. 1986. Modes of foreign entry: a transaction cost analysis and propositions. Journal of International Business Studies, 24, (2), 209-230.

Anderson, J.C. and Gerbing, D.W. 1988. Structural equation modeling in practice: A review and recommended two-step approach. Psychological Bulletin, 103, (3), 411-423.

ASCER (2004), Los sectores español y mundial de fabricantes de baldosas cerámicas, ASCER, Castellón.

ASCER. (2009), http://www.spaintiles.info. Website consulted in Fall 2009.

Assopiastrelle. (2009), http://www.italiatiles.com. Website consulted in Fall 2009.

Atuahene-Gima, K. 1995. The influence of new product factors on export propensity and performance: An empirical analysis. Journal of International Marketing, 3(2): 11-29.

Balabanis, G., Theodosiou, M. and Katsikea, E. 2004. Export marketing: Developments and a research agenda. International Marketing Review, 21,(4/5), 353-377.

Basile, R. 2001. Export Behaviour of Italian manufacturing firms over the nineties: the role of innovation. Research Policy, 30, 1185-1201.

Bonaccorsi, A. 1992. On the relationship between firm size and export intensity. Journal of International Business Studies, 23, 605-635. 
Boter, H., and Holmquist, C. 1996. Industry characteristics and internationalisation processes in small firms, Journal of Business Venturing, 11, 471-87.

Brouthers, L.E., Nakos, G., Hadjimarcou, J., and Brouthers, K.D. 2009. Key success factors for successful export performance for small firms. Journal of International Marketing, 17(3), 21-38.

Cadogan, J.W., Kuivalainen, O., and Sundqvist, S. 2009. Export market-oriented behavior and export performance: Quadratic and moderating effects under differing degrees of market dynamism and internationalization. Journal of International Marketing, 17(4), 71-89.

Calantone, R.J., Cavusgil, S.T. and Zhao, Y. 2002. Learning orientation, firm innovation capability, and firm performance. Industrial Marketing Management, 31, 515-524.

Camisón-Zornoza, C., Lapiedra-Alcamí, R., Segarra-Ciprés, M. and Boronat-Navarro, M. 2004. A meta-analysis of innovation and organizational size. Organization Studies, 25(3), 331-361.

Chamber of Commerce of Valencia 2004. Informe de la nueva economía global y su incidencia en los sectores tradicionales de la Comunidad Valenciana. Chamber of Commerce of Valencia, Valencia.

Chetty, S.K., and Hamilton, R.T. 1993. Firm-level determinants of export performance: a meta-analysis, International Marketing Review, 10(3), 26-34.

Chiva, R. and Alegre, J. 2005. Organizational learning and organizational knowledge: towards the integration of two approaches. Management Learning. 36, (1), 49-68.

Chiva, R. and Alegre, J. 2009a. Organizational learning capability and job satisfaction: An empirical assessment in the ceramic tile industry. British Journal of Management, 20(3): 323-340.

Chiva, R. and Alegre, J. 2009b. Investment in design and firm performance: the mediating role of design management. Journal of Product innovation Management, 26: 424-440.

Damanpour, F. and Evan, W.M. 1984. Organizational innovation and performance: the problem of organizational lag. Administrative Science Quarterly, 29, 392-409.

Dhanaraj, C., and Beamish, P.W. 2003. A resource-based approach to the study of export performance. Journal of Small Business Management, 41(3), 242-261.

DiBella, A.J., Nevis, E.C. and Gould, J.M. 1996. Understanding organizational learning capability. Journal of Management Studies, 33,(3), 361-379.

Enright, M.J. and Tenti, P. 1990. How the diamond works: The Italian ceramic tile industry. Harvard Business Review, March-April, 90-91. 
Fahy, J. 2002. A resource-based analysis of sustainable competitive advantage in a global environment. International Business Review, 11, 57-78.

Fernández, Z., and Nieto, M. J. 2005. Internationalization strategy of small and medium-sized family businesses: Some influential factors, Family Business Review, 18(1), 77-89.

Filatotchev, I., Dyomina, N., Wright, M. and Buck, T. 2001. Effects of post-privatization governance and strategies on export intensity in the former Soviet Union. Journal of International Business Studies, 32(4): 853-872.

Flor, M. and Oltra, M.J. 2005. The influence of firms' technological capabilities on export performance in supplier-dominated industries: the case of ceramic tile firms. $R \& D$ Management, 35(3), 333-347.

Gatignon, H., Tushman, M.L., Smith, W., and Anderson, P. 2002. A structural approach to assessing innovation: construct development of innovation locus, type and characteristics. Management Science, 48, (9), 1103-1122.

Gerbing, D.W. and Anderson, J.C. 1988. An updated paradigm for scale development incorporating unidimensionality and its assessment. Journal of Marketing Research, 25, 186-192.

Goh, S. and Richards, G. 1997. Benchmarking the learning capability of organizations. European Management Journal, 15, (5), 575-83.

Golovko, E. and Valentini, G. 2011. Exploring the complementarity between innovation and export for SMEs' growth. Journal of International Business Studies, 42, 362-380.

Grupp, H. 1997. The links between competitiveness, firms' innovative activities and public R\&D support in Germany: An empirical analysis. Technology Analysis \& Strategic Management, 9, (1), 19-33.

Hair, H.F., Anderson R.E., Tatham, R.L. and Black, W.C. 1998. Multivariate Data Analysis. Prentice Hall, London.

Hurley, R. F., and Hult, G. T. M. 1998. Innovation, market orientation, and organizational learning: An integration and empirical examination. Journal of Marketing, 62(3), 42-54.

Hult, G.T.M., Hurley, R.F. and Knight, G.A. 2004. Innovativeness: Its antecedents and impact on business performance. Industrial Marketing Management, 33, 429-438.

Hutzschenreuter, T., Pedersen, T. and Volberda, H.W. 2007. The role of path dependency and managerial intentionality: A perspective on international business. Journal of International Business Studies, 38, (7), 1055-1068.

Kafouros, M.I., Buckley, P.J., Shapr, J.A. and Wang, C. 2008. The role of internationalization in explaining innovation performance. Technovation, 28, 63-74. 
Katsikeas, C.S., Leonidou, L.C. and Morgan, N.A. 2000. Firm-level export performance assessment: review, evaluation, and development. Journal of the Academy Market Science, 28(4), 493-511.

Lages, L.F., Silva, G., and Styles, C. (2009), "Relationship capabilities, quality, and innovation as determinants of export performance," Journal of International Marketing, 17(4), 47-70.

Leonidou, L. 1995. Export barriers: Non-exporters perceptions. International Marketing Review, 12, (1), 4-25.

Leonidou, L., Katsikeas, C., and Piercy, N.F. 1998. Identifying managerial influences on exporting: past research and future directions. Journal of International Marketing, 6(2), 74-102.

Li, T.; Nicholls, J.A.F. and Roslow, S. 1998. The relationship between market-driven learning and new product success in export markets. International Marketing Review, 16(6), 476-503.

Ling-Yee, L. 2004. An examination of the foreign market knowledge of exporting firms based in the People's Republic of China: Its determinants and effect on export intensity. Industrial Marketing Management, 33(7): 561-572.

López-Rodríguez, J. and García-Rodríguez, R. 2005. Technology and export behaviour: A resource-based view approach. International Business Review, 14, 539-557.

Lumpkin, G.T., and Dess, G.G. 1996. Clarifying the entrepreneurial orientation construct and linking it to performance. Academy of Management Review, 12(1), 135-172.

MacKenzie, S.B., Podsakoff, P.M., and Burke Jarvis, C. 2005. The problem of measurement model misspecification in behavioral and organizational research and some recommended solutions. Journal of Applied Psychology, 90(4), 710-30.

Majocchi, A., Bacchiocchi, E. and Mayrhofer, U. 2005. Firm size, business experience and export intensity in SMEs: A longitudinal approach to complex relationships. International Business Review, 14, 719-738.

Malhotra, N.K. 1993. Marketing Research: An Applied Orientation. Prentice-Hall, Englewood Cliffs, N.J.

McKee, D. 1992. An organizational learning approach to product innovation," Journal of Product Innovation Management, 9, (3), 232-245.

OECD. 2005. The measurement of scientific and technological activities. Proposed guidelines for collecting and interpreting technological data. OECD, Paris. 
Petersen, B., Pedersen, T. and Lyles, M.A. 2008. Closing gaps in foreign markets. Journal of International Business Studies, 39, (7), 1097-1113.

Piercy, N., Kaleke, A. and Katsikeas, C. 1998. Sources of competitive advantage in high performing exporting companies. Journal of World Business, 33, (4), 3787-393.

Pla-Barber, J. and Alegre, J. 2007. Analysing the link between export intensity, innovation and firm size in a science-based industry. International Business Review, 16 (3), 275-293.

Quintás, M.A., Vázquez, X.H., García, J.M. and Caballero, G. 2009. International generation of technology: An assessment of its intensity, motives and facilitators. Technology Analysis \& Strategic Management, 21 (6), 743-763.

Revilla, E. and Rodríguez, B. 2011. Team vision in product development: How knowledge strategy matters. Technovation, (in press).

Rogers, M. 2004. Networks, firm size and innovation. Small Business Economics, 22, 141153.

Roper, S. and Love, J.H. 2002. Innovation and export performance: evidence from the UK and German manufacturing plants. Research Policy, 31, 1087-1102.

Salomon, R. and Jin, B. 2008. Does knowledge spill to leaders or laggards? Exploring industry heterogeneity in learning by exporting. Journal of International Business Studies, $39,(1), 132-150$.

Sousa, C., Martínez-López., F.J., and Coelho, F. 2008. The determinants of export performance: a review of the research in the literature between 1998 and 2005. International Journal of Management Reviews, 10 (2), 1-32.

Tippins, M.J. and Sohi, R.S. 2003. IT competency and firm performance: is organizational learning a missing link? Strategic Management Journal, 24, 745-761.

Toften, K. and Olsen, S.A. 2003. Export market information use, organizational knowledge and firm performance. International Marketing Review, 20(1), 95-110.

Volberda,H.W., Foss, N.J. and Lyles, M.A. 2010. Absorbing the Concept of Absorptive Capacity: How to Realize Its Potential in the Organization Field. Organization Science, 21(4): 931-945

Wang, C.L. 2008. Entrepreneurial Orientation, Learning Orientation, and Firm Performance. Entrepreneurship: Theory and Practice, 32, 635-657.

Wheelwright, S.C. and Clark, K.B. 1992. Revolutionizing Product Development - Quantum Leaps in Speed, Efficiency, and Quality. The Free Press, New York. 
Wu, C.H. and Fang, K. 2010. Improving project performance through organizational learning: An empirical study in Taiwan. Technology Analysis \& Strategic Management, 22(2) 261-276.

Zaltman, G, Duncan, R., and Holbek, J. 1973. Innovations and Organizations. Wiley, NY.

Zhou, K.Z., Yim, C.K. and Tse, D.K. 2005. The Effects of Strategic Orientations on Technology- and Market-Based Breakthrough Innovations. Journal of Marketing, 69(2), 42-60.

Zou, S. and Ozsomer, A. 1999. Global product R\&D and the firm's strategic position. Journal of International Marketing, 7(1), 57-77.

Zollo, M., and Winter, S.G. 2002. Deliberate learning and the evolution of dynamic capabilities. Organization Science, 13, 339-351. 
Table 1: Sample firm size and location

\begin{tabular}{|c|c|c|c|c|c|c|c|}
\cline { 2 - 8 } \multicolumn{1}{c|}{} & \multicolumn{9}{c|}{ Number of Employees } \\
\cline { 2 - 8 } \multicolumn{1}{c|}{} & $\begin{array}{c}\text { (1) Fewer } \\
\text { than 25 }\end{array}$ & $\begin{array}{l}\text { (2) Between } \\
\text { 25 and 49 }\end{array}$ & $\begin{array}{l}\text { (3) Between } \\
50 \text { and 99 }\end{array}$ & $\begin{array}{l}\text { (4) Between } \\
100 \text { and 199 }\end{array}$ & $\begin{array}{l}\text { (5) Between } \\
\text { 200 and 300 }\end{array}$ & $\begin{array}{l}\text { (6) Over } \\
300\end{array}$ & Total \\
\hline $\begin{array}{c}\text { Italian } \\
\text { Firms }\end{array}$ & 5 & 12 & 19 & 18 & 7 & 21 & 82 \\
\hline $\begin{array}{c}\text { Spanish } \\
\text { Firms }\end{array}$ & 6 & 21 & 42 & 18 & 8 & 5 & 100 \\
\hline Total & 11 & 33 & 61 & 36 & 15 & 26 & 182 \\
\hline
\end{tabular}


Table 2: Factor correlations, means, standard deviations, and reliabilities

\begin{tabular}{|c|c|c|c|c|c|c|c|c|c|c|c|c|}
\hline & Mean & S.D. & $\begin{array}{l}\text { Composite } \\
\text { Reliability }\end{array}$ & 1 & 2 & 3 & 4 & 5 & 6 & 7 & 8 & 9 \\
\hline 1. EXP & 5.24 & 1.13 & 0.76 & $(0.74)$ & & & & & & & & \\
\hline 2. RISK & 4.58 & 1.39 & 0.71 & $0.53 * *$ & $(0.70)$ & & & & & & & \\
\hline 3. ENV & 4.78 & 1.34 & 0.82 & $0.59 * *$ & $0.60^{* *}$ & $(0.82)$ & & & & & & \\
\hline 4. DIALOG & 5.48 & 1.08 & 0.83 & $0.60 * *$ & $0.38 * *$ & $0.52 *$ & $(0.83)$ & & & & & \\
\hline 5. PARTICIP & 4.58 & 1.41 & 0.87 & $0.45 * *$ & $0.56^{* *}$ & $0.62 * *$ & $0.48 * *$ & $(0.88)$ & & & & \\
\hline $\begin{array}{l}\text { 6. INNOVATION } \\
\text { EFFECTIVENESS }\end{array}$ & 5.08 & 1.11 & 0.91 & $0.48 * *$ & $0.38 * *$ & $0.46^{* *}$ & $0.55^{* *}$ & $0.33 * *$ & $(0.91)$ & & & \\
\hline $\begin{array}{l}\text { 7. INNOVATION } \\
\text { EFFICIENCY. }\end{array}$ & 4.69 & 1.21 & 0.91 & $0.44 * *$ & $0.41 * *$ & $0.48^{* *}$ & $0.54 * *$ & $0.42 * *$ & $0.84 * *$ & $(0.92)$ & & \\
\hline 8. SIZE & 3.33 . & 1.44 & -- & $0.31 * *$ & $0.40 * *$ & $0.34 * *$ & $0.23 * *$ & $0.29 * *$ & $0.33 * *$ & $0.40 * *$ & -- & \\
\hline $\begin{array}{l}\text { 9. EXPORT } \\
\text { INTENSITY }\end{array}$ & 44.76 & 19.25 & -- & $0.47 * *$ & $0.35 * *$ & $0.45 * *$ & $0.57 * *$ & $0.38^{* *}$ & $0.73 * *$ & $0.70 * *$ & $0.36^{* *}$ & -- \\
\hline
\end{tabular}

$\mathrm{N}=182$; alpha reliabilities are shown in brackets on the diagonal.

** Correlation is significant at the 0.01 level. 
Table 3: Pairwise Confirmatory Analyses for OLC: Estimates of Correlations

\begin{tabular}{|c|c|c|c|c|c|c|c|c|c|c|c|c|c|c|c|c|c|c|c|c|}
\hline \multirow[t]{2}{*}{ OLC } & \multicolumn{5}{|c|}{ EXPERIMENTATION } & \multicolumn{5}{|c|}{ RISK TAKING } & \multicolumn{5}{|c|}{$\begin{array}{l}\text { INTERACTION WITH EXTERNAL } \\
\text { ENVIRONMENT }\end{array}$} & \multicolumn{5}{|c|}{ DIALOGUE } \\
\hline & $\phi$ & d.f. & $\chi^{2}$ & $\Delta \chi^{2}$ & $\mathrm{p}$ & $\phi$ & d.f. & $\chi^{2}$ & $\Delta \chi^{2}$ & $\mathrm{p}$ & $\phi$ & d.f. & $\chi^{2}$ & $\Delta \chi^{2}$ & $\mathrm{p}$ & $\phi$ & d.f. & $\chi^{2}$ & $\Delta \chi^{2}$ & $\mathrm{p}$ \\
\hline RISK & $\begin{array}{c}0.72 \\
1 \\
0\end{array}$ & $\begin{array}{l}1 \\
2 \\
2\end{array}$ & $\begin{array}{c}3.16 \\
19.57 \\
77.16\end{array}$ & $\begin{array}{l}16.41 \\
74.00\end{array}$ & $\begin{array}{l}0.07 \\
0.00 \\
0.00\end{array}$ & & & & & & & & & & & & & & & \\
\hline ENV & $\begin{array}{c}0.77 \\
1 \\
0\end{array}$ & $\begin{array}{l}4 \\
5 \\
5\end{array}$ & $\begin{array}{c}9.36 \\
20.40 \\
109.73 \\
\end{array}$ & $\begin{array}{c}11.04 \\
100.37 \\
\end{array}$ & $\begin{array}{l}0.05 \\
0.00 \\
0.00\end{array}$ & $\begin{array}{c}0.82 \\
1 \\
0\end{array}$ & $\begin{array}{l}4 \\
5 \\
5 \\
\end{array}$ & $\begin{array}{c}10.41 \\
15.19 \\
110.78\end{array}$ & $\begin{array}{c}4.78 \\
100.37\end{array}$ & $\begin{array}{l}0.04 \\
0.00 \\
0.00\end{array}$ & & & & & & & & & & \\
\hline DIALOG & $\begin{array}{c}0.77 \\
1 \\
0\end{array}$ & $\begin{array}{l}8 \\
9 \\
9 \\
\end{array}$ & $\begin{array}{c}7.75 \\
17.07 \\
93.17 \\
\end{array}$ & $\begin{array}{c}9.32 \\
85.42 \\
\end{array}$ & $\begin{array}{l}0.46 \\
0.04 \\
0.00\end{array}$ & $\begin{array}{c}0.53 \\
1 \\
0 \\
\end{array}$ & $\begin{array}{l}8 \\
9 \\
9 \\
\end{array}$ & $\begin{array}{l}10.65 \\
17.67 \\
57.71 \\
\end{array}$ & $\begin{array}{c}7.02 \\
47.06\end{array}$ & $\begin{array}{l}0.22 \\
0.03 \\
0.00 \\
\end{array}$ & $\begin{array}{c}0.64 \\
1 \\
0\end{array}$ & $\begin{array}{l}13 \\
14 \\
14 \\
\end{array}$ & $\begin{array}{l}21.79 \\
29.34 \\
85.24 \\
\end{array}$ & $\begin{array}{c}7.55 \\
63.45 \\
\end{array}$ & $\begin{array}{l}0.06 \\
0.01 \\
0.00\end{array}$ & & & & & \\
\hline PARTICIP & $\begin{array}{c}0.58 \\
1 \\
0\end{array}$ & $\begin{array}{l}4 \\
5 \\
5\end{array}$ & $\begin{array}{l}16.21 \\
50.26 \\
75.75\end{array}$ & $\begin{array}{l}30.05 \\
59.54\end{array}$ & $\begin{array}{l}0.06 \\
0.00 \\
0.00\end{array}$ & $\begin{array}{c}0.72 \\
1 \\
0\end{array}$ & $\begin{array}{l}4 \\
5 \\
5\end{array}$ & $\begin{array}{c}3.80 \\
12.20 \\
75.09\end{array}$ & $\begin{array}{c}8.40 \\
71.29\end{array}$ & $\begin{array}{l}0.43 \\
0.03 \\
0.00\end{array}$ & $\begin{array}{c}0.76 \\
1 \\
0\end{array}$ & $\begin{array}{l}8 \\
9 \\
9\end{array}$ & $\begin{array}{c}8.01 \\
14.33 \\
109.84\end{array}$ & $\begin{array}{c}6.32 \\
101.83\end{array}$ & $\begin{array}{l}0.43 \\
0.11 \\
0.00\end{array}$ & $\begin{array}{c}0.59 \\
1 \\
0\end{array}$ & $\begin{array}{l}13 \\
14 \\
14\end{array}$ & $\begin{array}{l}16.83 \\
40.01 \\
72.41\end{array}$ & $\begin{array}{l}23.18 \\
55.58\end{array}$ & $\begin{array}{l}0.21 \\
0.02 \\
0.00\end{array}$ \\
\hline
\end{tabular}

Table 4: Pairwise Confirmatory Analyses for Innovation Performance: Estimates of Correlations

\begin{tabular}{|c|c|c|c|c|c|}
\hline \multirow{2}{*}{$\begin{array}{c}\text { Product } \\
\text { Innovation } \\
\text { Performance }\end{array}$} & \multicolumn{5}{|c|}{ EFFECTIVENESS } \\
\cline { 2 - 6 } & $\phi$ & d.f. & $\chi 2$ & $\Delta \chi 2$ & $\mathrm{p}$ \\
\hline EFFICIENCY & 0.87 & 43 & 114.75 & & 0.00 \\
& 1 & 44 & 121.52 & 6.77 & 0.00 \\
& 0 & 2 & 296.80 & 182.05 & 0.00 \\
\hline
\end{tabular}


Figure 1: Direct effect model

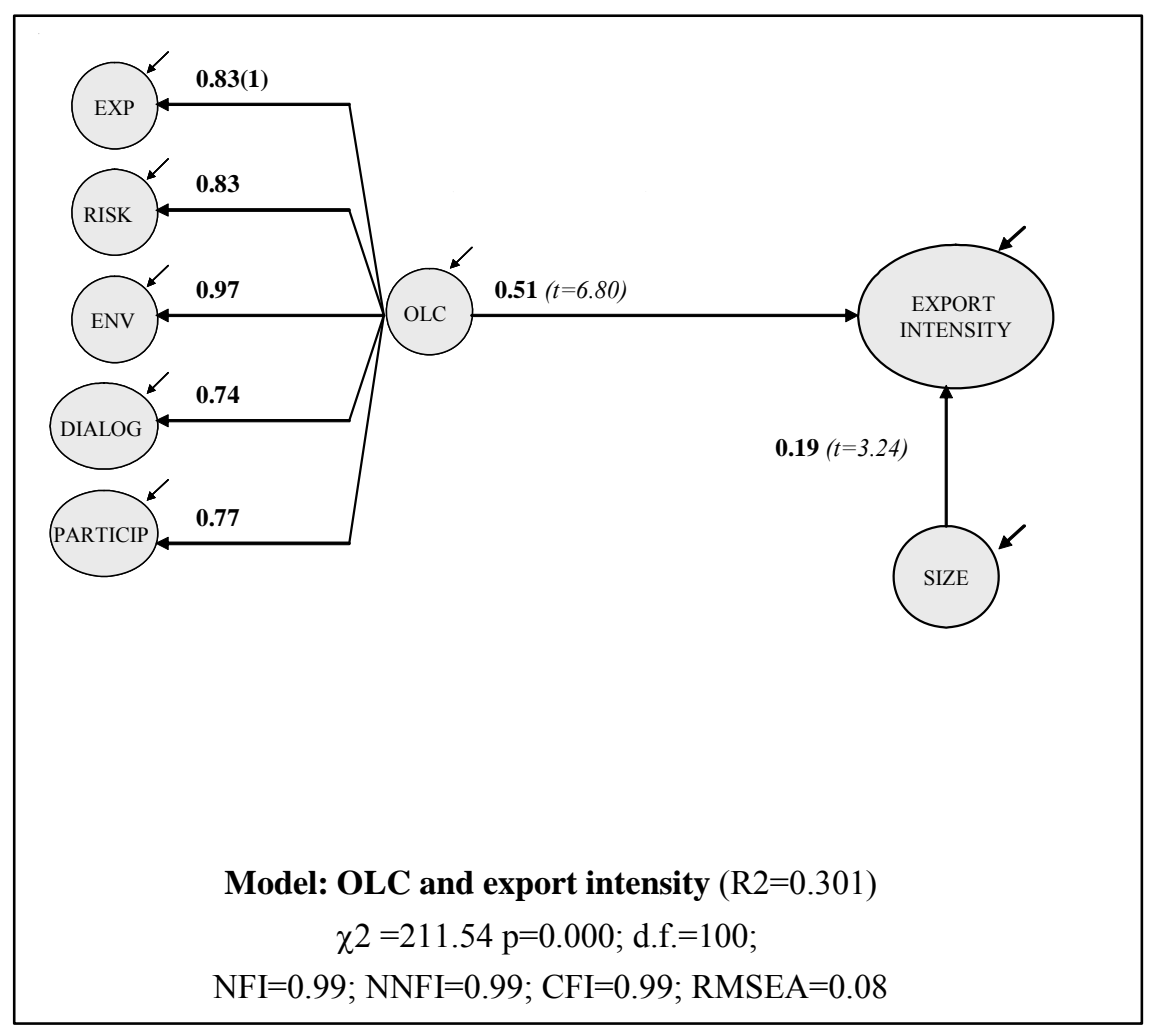

OLC is a second-order factor. For the sake of brevity, only the first-order loadings are shown. Parameter estimates are standardized. All parameters are significant at $\mathrm{p}<0.001$ except where indicated.

(1) The parameter was equaled to 1 to fix the latent variable scale. 
Figure 2: Partial mediation model

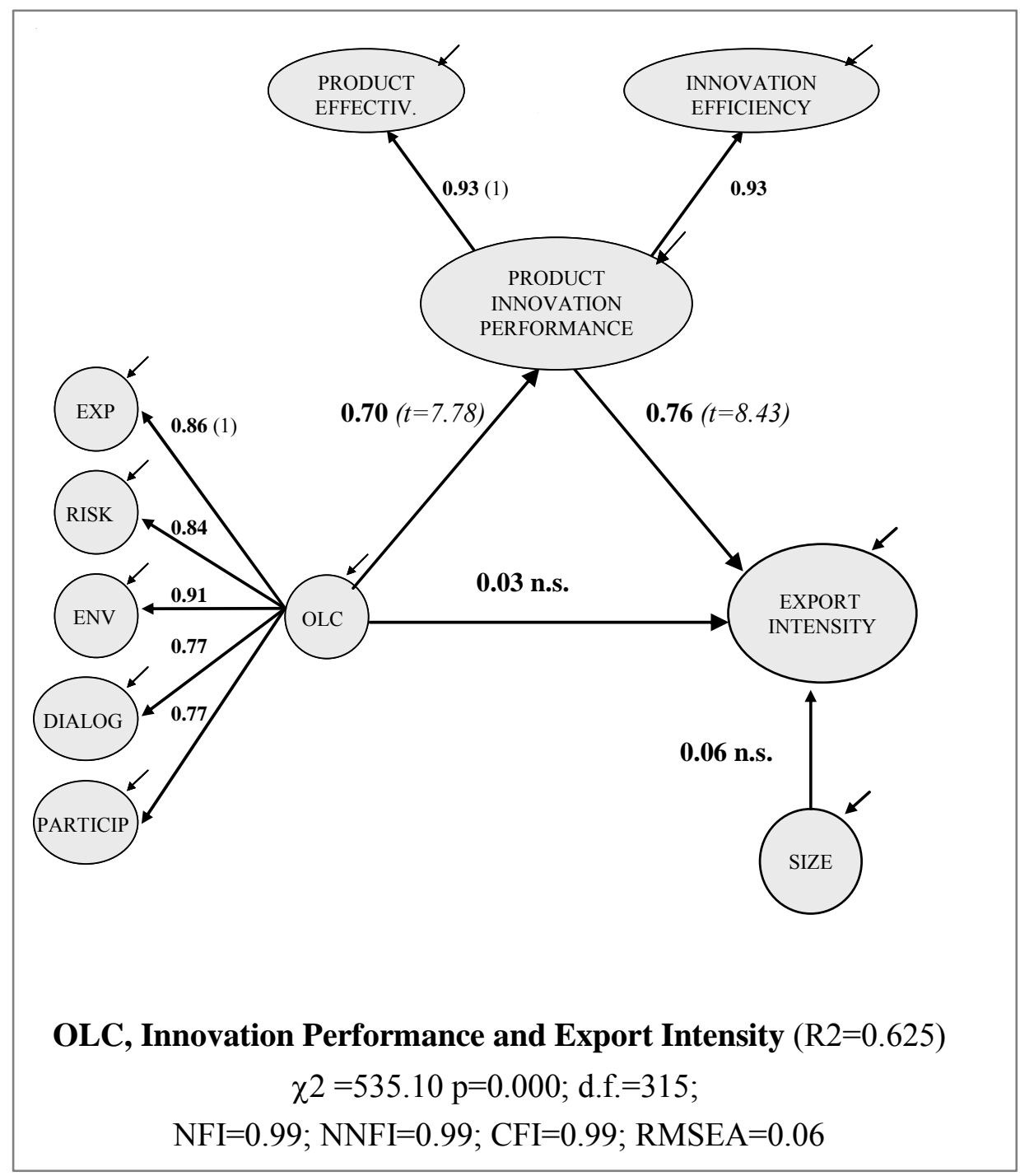

OLC and Product Innovation Performance are second-order factors. For the sake of brevity, only the first-order loadings are shown. Parameter estimates are standardized. All parameters are significant at $\mathrm{p}<0.001$ except where indicated.

(1) The parameter was equaled to 1 to fix the latent variable scale. 


\section{Appendix: Questionnaire}

Please assess the importance of the following items in your organization.

\begin{tabular}{|c|c|c|}
\hline Dimension & Item & Literature source \\
\hline \multirow{2}{*}{ Experimentation } & $\begin{array}{l}\text { EX1. People here receive support and encouragement when } \\
\text { presenting new ideas }\end{array}$ & \multirow[t]{14}{*}{$\begin{array}{l}\text { Chiva and Alegre } \\
(2009 a)\end{array}$} \\
\hline & $\begin{array}{l}\text { EX2. Initiative often receives a favorable response here so people } \\
\text { feel encouraged to generate new ideas }\end{array}$ & \\
\hline \multirow{2}{*}{ Risk taking } & RK1. People are encouraged to take risks in this organization & \\
\hline & RK2. People here often venture into unknown territory. & \\
\hline \multirow{3}{*}{$\begin{array}{l}\text { Interaction with the } \\
\text { environment }\end{array}$} & $\begin{array}{l}\text { EN1. It is part of the work of all staff to collect, bring back, and } \\
\text { report information about what is going on outside the company. }\end{array}$ & \\
\hline & $\begin{array}{l}\text { EN2. There are systems and procedures for receiving, collating and } \\
\text { sharing information from outside the company. }\end{array}$ & \\
\hline & $\begin{array}{l}\text { EN3. People are encouraged to interact with the environment: } \\
\text { competitors, customers, technological institutes, universities, } \\
\text { suppliers etc. }\end{array}$ & \\
\hline \multirow{4}{*}{ Dialogue } & DG1. Employees are encouraged to communicate. & \\
\hline & $\begin{array}{l}\text { DG2. There is a free and open communication within my work } \\
\text { group }\end{array}$ & \\
\hline & DG3. Managers facilitate communication & \\
\hline & DG4. Cross-functional teamwork is a common practice here. & \\
\hline \multirow{3}{*}{$\begin{array}{l}\text { Participative decision } \\
\text { making }\end{array}$} & $\begin{array}{l}\text { PA1. Managers in this organization frequently involve employees } \\
\text { in important decisions }\end{array}$ & \\
\hline & PA2. Policies are significantly influenced by the view of employees & \\
\hline & PA3. People feel involved in main company decisions & \\
\hline
\end{tabular}

Please assess the importance of the following items in your organization.

\begin{tabular}{|l|l|l|}
\hline Dimension & Item & Literature source \\
\hline \multirow{4}{*}{$\begin{array}{l}\text { Product innovation } \\
\text { PT1. Replacement of products being phased out }\end{array}$} & $\begin{array}{l}\text { OECD (2005); Alegre } \\
\text { et al. (2009) }\end{array}$ \\
$\begin{array}{l}\text { PT2. Extension of product range within main product field through } \\
\text { new products }\end{array}$ & \\
& PT3. Extension of product range outside main product field \\
\cline { 2 - 2 } & PT4. Development of environment-friendly products & \\
\cline { 2 - 2 } & PT5. Market share evolution & \\
\cline { 2 - 3 } & PT6. Opening of new markets abroad & \\
\cline { 2 - 3 } & PT7. Opening of new domestic target groups & \\
\hline
\end{tabular}

\begin{tabular}{|l|l|l|}
\hline \multirow{3}{*}{$\begin{array}{l}\text { Product innovation } \\
\text { efficiency }\end{array}$} & EF1. Average innovation project development time & \\
& EF2. Average number of innovation project working hours \\
\cline { 2 - 2 } & EF3. Average cost per innovation project \\
\cline { 2 - 2 } & $\begin{array}{l}\text { EF4. Degree of overall satisfaction with innovation project } \\
\text { efficiency }\end{array}$ & \\
\hline
\end{tabular}

